\title{
Chapter 14 \\ Access to Social Protection by Immigrants, Emigrants and Resident Nationals in the Russian Federation
}

\author{
Daria Popova
}

\subsection{Overview of the National Social Security System and Main Migration Features in the Russian Federation}

This chapter discusses the general legal framework regulating Russia's welfare system and access for national citizens, foreigners residing in the country, and national citizens residing abroad to social benefits in five policy areas: unemployment, health care, family benefits, pensions, and guaranteed minimum resources.

\subsubsection{Main Characteristics of the National Social Security System}

The current Russian federal system comprises a complex structure of social responsibilities divided between the federal and regional Governments. Pensions and contributory social transfers are regulated at the federal level and financed from social insurance contributions (SIC) and general taxes. As a result of the decentralization reform carried out in 2005, the majority of responsibilities for legislative regulation and financing of non-contributory social transfers and services were transferred from the federal to the regional level. Regional authorities may set the size and eligibility criteria within the limits established by the federal legislation. Despite partial privatization, healthcare remains to a large extent public and free at the point of use, but there are user fees for services beyond the basic coverage and informal payments are still quite widespread in healthcare. Public healthcare is funded

\footnotetext{
D. Popova $(\bowtie)$

Institute for Social and Economic Research, University of Essex, Essex, UK

e-mail: dpopova@essex.ac.uk
} 
through SIC and general taxes. There is a high regional disparity in spending on non-contributory social benefits and healthcare.

The social protection programmes are funded from the Consolidated Budget of the Russian Federation (which comprises federal, regional and municipal budgets) and extra-budgetary funds (the Pension Fund, the Social Insurance Fund, the Federal and Territorial Funds of Mandatory Health Insurance). Revenues of extra-budgetary funds are financed by SIC paid by employers (on behalf of employees) and the selfemployed. The revenues of the Consolidated Budget are derived from general taxes (federal, regional and local). In total, the contribution of the Consolidated Budget amounts to over a half of the total social protection spending.

Since the mid-2000s and until the economic crisis which began in the second half of 2014, social spending in Russia had been expanding. Yet, recent studies categorize the Russian tax-benefit system as not very redistributive (Lopez-Calva et al. 2017; Popova et al. 2018). The social protection system is dominated by pensions and categorical benefits which are mainly targeted at people of old age. Government transfers cover a large share of the population, but most cash benefits do not reach the subsistence level. The attempts to reduce the number of eligible people by introducing means-testing procedures were largely unsuccessful. In 2005, a reform aimed at monetizing the categorical in-kind benefits (former "privileges") resulted in massive public protests. The failure of that reform set limits to further structural changes in social policies. The 'national projects' initiated in 2006 proposed increases in financing of social programmes without any significant restructuring. The Government has implemented a series of increases in earnings of the public sector workers, the minimum wage, pension benefits and a revision of maternity and childcare benefits aimed at promoting the falling fertility rates. At the same time, despite the inflow of energy revenues, the fiscal capacities of the state remain limited due to poorly regulated social insurance markets and large scale informality and tax avoidance.

Table 14.1 shows the breakdown of social spending by main social programmes in Russia since mid-2000s. Total social spending (including public healthcare and social protection), accounted for $16.6 \%$ of the Gross Domestic Product (GDP) in 2015. Healthcare expenditures remained constant at 3.7\% of the GDP, while social protection spending have dropped since 2010 due to austerity measures associated with the 2014 economic crisis. A significant part of social protection spending goes to public contributory and non-contributory pensions (8.2\% of the GDP in 2015). Spending on social insurance or contributory benefits and quasi-insurance unemployment benefit accounted for $0.8 \%$ of the GDP in 2015. Spending on noncontributory social assistance programs accounted for $2.4 \%$ of the GDP, but a major part of these resources was spent on categorical benefits for the elderly. Meanstested benefits for the poor remain underdeveloped, accounting only for $0.4 \%$ of GDP in 2015. The costs of various social services (including social care, childcare, youth policy and other programs) amounted to 2.1\% of the GDP in 2015. 
14 Access to Social Protection by Immigrants, Emigrants and Resident Nationals...

Table 14.1 Social spending in Russia (in mln rubles and as \% of GDP)

\begin{tabular}{|c|c|c|c|}
\hline Year & 2005 & 2010 & 2015 \\
\hline \multicolumn{4}{|l|}{ In current prices, mln rubles } \\
\hline Social spending, total & $2,909,487$ & $8,032,267$ & $13,765,296$ \\
\hline Healthcare, physical culture and sports & 797,056 & $1,708,805$ & $3,115,864$ \\
\hline Social protection & $2,112,431$ & $6,323,462$ & $10,649,432$ \\
\hline Pensions & $1,292,988$ & $3,881,632$ & $6,855,119$ \\
\hline Unemployment benefit and ALMPs & 26,383 & 183,884 & 43,210 \\
\hline Social insurance/contributory & 134,090 & 456,617 & 639,048 \\
\hline Maternity leave allowance & 14,534 & 67,317 & 116,685 \\
\hline $\begin{array}{l}\text { Lump-sum allowance on childbirth/adoption/family } \\
\text { placement }\end{array}$ & 8479 & 18,737 & 22,251 \\
\hline Childcare allowance up to 1.5 years & 5670 & 121,797 & 142,312 \\
\hline Temporary incapacity benefit & 95,669 & 185,183 & 196,684 \\
\hline Workplace accident/work-related disease insurance covers & 28,833 & 46,315 & 70,562 \\
\hline Social assistance/non-contributory & 405,670 & $1,270,621$ & $1,967,965$ \\
\hline Not means-tested benefits & 322,306 & $1,032,367$ & $1,641,609$ \\
\hline Monthly cash payments (categorical benefits) & 179,989 & 516,241 & 706,760 \\
\hline Other categorical benefits (cash and in kind) & 133,691 & 401,357 & 546,723 \\
\hline Special forms of support for families with children & & 114,770 & 388,127 \\
\hline Means-tested benefits & 83,365 & 238,253 & 326,356 \\
\hline Child allowance up to 16(18) years & 18,135 & 43,607 & 46,447 \\
\hline Housing subsidies & 40,035 & 55,719 & 62,757 \\
\hline State social assistance & 1629 & 8305 & 18,211 \\
\hline Social supplement to pension & 23,566 & 130,622 & 158,331 \\
\hline Social care institutions & 70,234 & 168,630 & 251,958 \\
\hline Other social programmes & 45,272 & 158,262 & 703,239 \\
\hline Childcare and pre-school education & 112,998 & 321,349 & 692,087 \\
\hline Youth policy & 24,796 & 49,511 & 58,405 \\
\hline \multicolumn{4}{|l|}{ As $\%$ of $G D P$} \\
\hline Social spending, total & 13.5 & $\mathbf{1 7 . 3}$ & 16.6 \\
\hline Healthcare, physical culture and sports & 3.7 & 3.7 & 3.7 \\
\hline Social protection & 9.8 & 13.7 & 12.8 \\
\hline Pensions & 6.0 & 8.4 & 8.2 \\
\hline Unemployment benefit and ALMPs & 0.1 & 0.4 & 0.1 \\
\hline Social insurance & 0.6 & 1.0 & 0.8 \\
\hline Social assistance & 1.9 & 2.7 & 2.4 \\
\hline Not means-tested benefits & 1.5 & 2.2 & 2.0 \\
\hline Means-tested benefits & 0.4 & 0.5 & 0.4 \\
\hline Social care & 0.3 & 0.4 & 0.3 \\
\hline Other social programmes & 0.2 & 0.3 & 0.8 \\
\hline Childcare and pre-school education & 0.5 & 0.7 & 0.8 \\
\hline Youth policy & 0.1 & 0.1 & 0.1 \\
\hline GDP in current prices, bln rubles & $21,609.8$ & $46,308.5$ & $83,101.1$ \\
\hline
\end{tabular}


Table 14.1 (continued)

\begin{tabular}{l|l|l|c}
\hline Year & 2005 & 2010 & 2015 \\
\hline GDP growth & 106.4 & 104.5 & 97.5 \\
\hline CPI end-year & 110.9 & 108.8 & 112.9 \\
\hline
\end{tabular}

Sources: Calculated by Elena Gorina using the data of the Federal Treasury at http://www. roskazna.ru (reports on implementation of the consolidated budget of RF and budgets of state extra-budgetary funds, Federal Budget of RF, consolidated budgets of regions); federal laws on implementation of the budget of the pension fund and social insurance fund; regional laws on implementation of budgets of regions; Federal State Statistics Service data (statistical digest "social situation and standard of living of the population of Russia") at http://www.gks. $\mathrm{ru} /$;Federal employment service data at http://www.rostrud.ru/

\subsubsection{Migration History and Key Policy Developments}

The migration situation in Russia has been developing according to a scenario of migration in Western Europe, but lagging by 30 to 40 years. In the 1960s, Europe experienced postcolonial migration flows; currently, the situation in Russia resembles the one in Western Europe in the late 1970s. As of 2017, Russia hosted 11,7 million international migrants which accounted for $8.1 \%$ of the total population (UN DESA 2017). However, the majority of these international migrants comes from the former Soviet Union republics, with the three largest contributors being Ukraine, Kazakhstan and Uzbekistan. The balance of international migration increased sharply after the collapse of the Soviet Union, reaching its highest level in the mid-1990s (845,7 thousand people, or 5.7 per 1000 people in 1994) (Rosstat 2017). This was due to the massive flow of Russian expatriates returning to Russia from other states of the former Soviet Union. Subsequently, there was a decrease in the intensity of international migration until mid-2000s. Starting from late 2000s, the balance of international migration has been rapidly growing again due to the inflow of temporary economic migrants from less developed Central Asian states, including Kyrgyzstan, Tajikistan, Turkmenistan and Uzbekistan. Currently, these are the main group of working migrants in Russia (Di Bartolomeo et al. 2014). In 2015-2016, the number of migrant workers shrank by at least one third after a nearly two-fold depreciation of national currency and the contraction of the Russian labour market, but this seems to be a temporary trend (Rosstat 2017).

At the same time, in 2017, 10,6 million people born in Russia lived abroad (UN DESA 2017). Among those, three quarters were in former Soviet Union republics. Of those not living in the former Soviet Union countries, the majority are ethnic migrants who took part in repatriation programs which enabled them to settle in Germany, the United States and Israel. Overall, the top destination countries for Russian emigration over the period since the collapse of the Soviet Union were Ukraine, Germany and Kazakhstan.

Russia's migration policy has been rather ambiguous. Russia has established a visa-free regime with countries of the Commonwealth of Independent States (CIS) which allows citizens of these countries to stay in Russia temporarily and look for work. However, a lack of transparent and flexible labour migration policy has 
pushed a major share of them into undeclared work. Estimates of the number of undocumented migrants working in Russia vary from 3-4 million in autumn and winter to 5-7 million in spring and summer due to seasonal work (Iontsev and Ivakhnyuk 2012). They mostly hold low-paying jobs, primarily in trade and construction, which are unattractive to Russian citizens. Widespread undeclared employment of migrants is associated with considerable financial losses for Russia in the form of unpaid taxes and social contributions. At the same time, this group of migrants is deprived in terms of their employment and social rights and have sometimes been met with xenophobia.

Politically, Russia is interested in strengthening integration of the post-Soviet space and considers interaction with CIS countries a priority of its migration policy. The demographic developments over the past 20 years (low fertility rates and population ageing) make Russia increasingly dependent on foreign workforce. Yet, only recently has the Russian Government started elaborating a migration policy that accounts for labour market needs. The State Migration Policy Concept (2012) sets policy until 2025 aiming to make immigration policy more balanced and includes the development of legislation focused on various (primarily labour) migration flows.

One of the major developments in migration policy has been the launch of the Eurasian Economic Union (EAEU), which comprises Russia, Belarus, Kazakhstan, Armenia and Kyrgyzstan. Citizens of these countries are subject to preferential migration regime which makes them equal to Russian nationals in terms of their employment and social security rights (and vice versa). At the same time, new regulations introduced in 2015 made it more difficult and costly for other migrants to access the Russian labour market on a legal basis. All potential employees are now required to pass Russian language tests, undergo a medical exam and purchase voluntary health insurance. Finally, integration of migrants still receives little policy attention, which remains a major challenge.

\subsection{Migration and Social Protection in the Russian Federation}

The main legislative act regulating the rights and obligations of foreigners in Russia is the Federal Law No 115 of July 2002. The Law defines three main types of migrant statuses that condition foreigners' access to social benefits: temporary visitors (on a migration card/visa), temporary residents (on a temporary residence permit), and permanent residents (on a residence permit) ${ }^{1}$.

\footnotetext{
${ }^{1}$ Foreigners can apply for a status of a permanent resident within three years after having obtained a temporary residence permit. The procedure implies passing the Russian language proficiency test (with the exception of citizens of Belarus, pensioners and minors) or providing the certificate of secondary education obtained in the Soviet Union or Russia; medical exam; confirmation of means (income above the subsistence level); state duty. Some individuals are eligible for the simplified
} 
Social security benefits are financed from extra-budgetary funds that receive their revenues from social contributions made by the working population. Hence, a personal contribution record determines the entitlement to receive social security benefits from these funds. Foreigners who are permanent or temporary residents are entitled to social security benefits if they are considered socially insured according to the law, if they work under an employment contract, or if their employer makes social insurance contributions on their behalf. The exception are all social benefits for families with children ${ }^{2}$. Foreigners who are permanent residents are entitled to receive them even if they do not have a contribution record, just like nationals. Foreigners who reside in the country on a temporary basis are only entitled to temporary incapacity and maternity benefits provided that they have been officially registered and made contributions to the Social Insurance Fund for at least six months. Neither permanent, nor temporary foreign residents are entitled to the cash unemployment benefit.

As for social assistance benefits, all foreigners legally residing in Russia can access these benefits under the same eligibility conditions as those applied for resident Russians. However, social assistance benefits will not be provided in cases of illegal residence and employment, work under a civil law contract, deprivation of parental rights or leaving children in full provision of the state.

All foreigners, regardless of their status in the Russian Federation, are eligible for free emergency medical care in public healthcare institutions. Only foreigners who are insured can receive other types of free healthcare. This applies to permanent or temporary foreign residents, as well as refugees. Temporary visitors are not eligible and are obliged to have a voluntary health insurance or pay for medical treatment. Temporary workers must have a certificate of voluntary medical insurance to be able to work on the territory of the Russian Federation.

A special group of foreign citizens who enjoy a preferential treatment in terms of accessing social benefits in Russia are citizens of the Republic of Belarus (based on a bilateral treaty of 2007) and citizens of the countries of the Eurasian Economic Union (EAEU ${ }^{3}$, which apart from Belarus and Russia, also includes Kazakhstan, Armenia and Kyrgyzstan). Insured citizens of these countries have the same rights of access to social security benefits (excluding pensions) as citizens of the state where they are employed.

The only type of social benefits that could be received by a non-resident Russian citizen is contributory pension. A temporary leave from Russia (without acquiring a status of a permanent resident in another country) will not affect the rights of Russian citizens to social benefits from Russia, as long as they fulfil the general eligibility conditions for those benefits.

procedure for obtaining a residence permit. These include: highly qualified workers and their family members, refugees, Russian native speakers, citizens of Turkmenistan and Belarus; participants of resettlement program for the expatriates, individuals married to Russian citizens.

${ }^{2}$ Federal Law No 81 of May 19, 1995 "On state benefits for citizens with children".

${ }^{3}$ See: http://www.eaeunion.org/?lang=en. Last accessed 5 May 2020. 


\subsubsection{Unemployment}

According to the Russian labour legislation ${ }^{4}$, there are several types of social support guaranteed by the state to the unemployed. The unemployment benefit in Russia is financed by general revenues and is weakly related to the length of service and earnings, hence can be considered as a quasi-insurance program. To be eligible for an earnings-related unemployment benefit, applicants should be employed at least for 26 calendar weeks of full-time employment during 12 months preceding the job loss. The benefit is conditional on applicant's registration with the employment service. During the first 12 months of unemployment, the amount of the benefit is defined as a proportion of applicant's average earnings for the last three months of employment, subject to minimum and maximum thresholds. After that period, the applicant might be entitled to the minimum amount of unemployment benefit. The unemployed lacking a sufficient insurance record (e.g. first-time job seekers, those who have exhausted their entitlements, those willing to start working after a year long break) and those dismissed due to violation of work discipline are entitled to the minimum amount of the unemployment benefit, while each period of the benefit payment cannot exceed six months during a 12-month period.

The public employment service provides early retirement pensions to the recipients of unemployment benefits and material aid to those unemployed who exhausted their eligibility for the cash benefit. In addition, there are cash benefits aimed at supporting the participation of job seekers in active labor market programs, including a training scholarship, wages for public works, etc.

Registered unemployment rates in Russia are substantially lower than surveybased unemployment rates (by International Labour Organization - ILO definition), predominantly due to limited incentives for registration, as the unemployment benefit amount is very low. However, registration of working age individuals at the employment service if they are not in work is a mandatory requirement for obtaining the means-tested social assistance. Only around one third of the unemployed is registered with the public employment service. The unemployment benefit is paid to nearly $90 \%$ of the registered unemployed and overall, recipients constitute less than $1 \%$ of the population (Rosstat 2018a).

Foreign residents cannot apply for the unemployment benefit as the latter is exclusively reserved for nationals. Russian citizens permanently residing abroad are not eligible either. However, foreigners may apply to the employment service in order to receive help with job search.

\footnotetext{
${ }^{4}$ The Labour Code of the Russian Federation (Federal Law of 30.12.2001 No 197); Federal Law of 19.04.1991 No 1032-1 "On employment in the Russian Federation".
} 


\subsubsection{Health Care}

Public healthcare is free at the point of use for Russian citizens ${ }^{5}$. The state guarantees free healthcare including in- and out-patient treatment, rehabilitation/nursing care and provision of medicine for specific categories of patients. However, free provision is currently quite limited, which results in the growth of private spending on healthcare services, including "additional" services provided by public medical institutions. Public healthcare for working people is funded through contributions paid by employers and the self-employed to the Federal and Territorial Mandatory Health Insurance Funds. The cost of health insurance for non-working citizens is covered from the regional budgets, with the share of healthcare spending subsidized by the budget being over $50 \%$.

All foreigners, regardless of their status, are eligible for free emergency medical care in public healthcare institutions ${ }^{6}$. Insured foreigners can also benefit from other types of public healthcare ${ }^{7}$. This applies to foreigners permanently residing in the country and refugees, irrespectively of their working status, and temporary nonnational employees. Uninsured women are also eligible for medical help during pregnancy and childbirth. Foreigners who are temporarily residing in the country are obliged to have a certificate of voluntary health insurance valid on the territory of the Russian Federation.

Health-related cash allowances are provided by the Social Insurance Fund (SIF) ${ }^{8}$. Its revenues are generated by social insurance contributions paid by employers and transfers of the federal budget to cover the costs of payments to some categories of uninsured persons. The Fund also accumulates employer contributions on mandatory workplace accidents and work-related disease insurance. The main healthrelated cash allowance - a temporary incapacity benefit - is paid to all insured persons (regardless of the nationality or the length of residence in Russia) for the whole period of absence from work due to sickness or the need to take care for a sick family member. The amount is estimated on the basis of annual earnings of the insured person over the past two years subject to an upper limit. The size of the benefit is differentiated by a length of the contribution record: $60 \%$ of average earnings for employees with less than five years employment record; $80 \%$ for employees with five to eight years record; $100 \%$ for those with more than eight years record; no more than the minimum wage for employees whose record is below six

\footnotetext{
${ }^{5}$ Federal Law No 323 of 21.11.2011 "On the basis of citizens' health protection in the Russian Federation".

${ }^{6}$ Government Decree No 186 of 6.03.2013 on the rules of providing medical care to foreign nationals on the territory of the Russian Federation.

${ }^{7}$ Federal Law No 326 of 29.11.2010 “On Compulsory Health Insurance", article 10.

${ }^{8}$ Federal Law No 165 of 16.07.1999 'On foundations of social insurance'; Federal Law No 255 of 29.12.2006 'On mandatory social insurance in case of temporary incapacity and maternity'; Federal Law No 125 of 24.07 .1998 'On mandatory social insurance in case of workplace accidents and work-related diseases'.
} 
months. The allowance is not exportable as being employed in Russia is a prerequisite for qualifying for this benefit.

The main cash allowance related to disability is the disability pension. In 2017, 2.183 million people (out of 43.177 million pensioners) received a disability pension (Rosstat 2018a). There are contributory and non-contributory (or social) disability pensions. The contributory ones are provided on the same conditions as old-age pensions, except that the former can be claimed irrespectively of age. Individuals without any contribution record (e.g. disabled children) are eligible for the non-contributory disability pensions. The size of disability pension depends on the severity of disability. The total number of recipients of disability pensions is lower than the total number of the disabled, because some of them choose to receive an old-age pension, which is higher for people with the easiest form of disability. Contributory disability pension can be exported outside of Russia, but noncontributory disability pensions are only available to those residing in Russia (nationals and permanent foreign residents).

\subsubsection{Pensions}

Since 2002, Russia maintains a three-pillar pension system: the first pillar is based on a pay-as-you-go (PAYG) principle, the second pillar is a funded system (for those born after 1966), whereas the third pillar provides mechanisms for additional savings towards a better pension on a voluntary basis ${ }^{9}$. The first two pillars are financed by contributions to the extra-budgetary Pension Fund paid by employers (on behalf of employees) and the self-employed. Russia also has a "zero" pillar or general revenue-financed benefits for uninsured pensioners (the disabled, orphans, etc.). Early retirement and postponement are possible and individuals are allowed to work while receiving a pension. The share of working pensioners amounts to about $30 \%$ since early 2000s (Rosstat 2018a). Currently, about half of the total budget of the Pension Fund is funded by transfers from the federal budget.

Contributory pensions are called labour pensions and comprise old age, disability and survivor's pensions. The pension formula has undergone several changes, the latest one in 2015. Currently, the eligibility for the contributory pension depends on an 'individual pension score' (pension points) calculated based on earnings, length of employment and age at retirement. The minimum contribution period to

\footnotetext{
${ }^{9}$ Federal Law No 167 of 15.12.2001 'On mandatory pension insurance in the Russian Federation'; Federal Law of 24.07.2002 'On investment of assets for financing the funded element of the labour pension in the Russian Federation'; Federal Law No 173 of 17.12.2001 'On labour pensions in the RF'; Federal Law No 166 of 15.12.2001 'On public pension provision in the RF'; Federal law No 56 of 30.04.2008 'On additional insurance premiums for the funded part of the labour pension and the state support for formation of pension savings'.
} 
be eligible for a contributory pension is 15 years (prior to 2015 - five years). Prior to January 2019, the retirement age was 55 years for women and 60 years for men ${ }^{10}$.

Social pensions are granted to individuals with insufficient or no labour record. This comprises all men aged $65+$ and women aged 55+, the disabled, childrenorphans studying full-time up to the age 23 and representatives of the small ethnic groups of the North upon reaching the age 55 for men and 50 for women. There is no means-test. In 2015, out of 41.456 million pensioners, 3.007 million received social pensions (Rosstat 2018a).

In order to receive a contributory pension, foreigners must have the status of permanent residents, be insured in the Russian system of mandatory pension insurance, and fulfill the general eligibility conditions. Social pension may be granted to foreigners permanently residing in Russia if they lived in the country for at least 15 years and reached the state retirement age. Foreigners temporarily residing in Russia are not entitled to claim public pension until they receive a permanent residency status or citizenship. However, the pension rights of foreigners may also be regulated by bilateral agreements. Under such an agreement, pension rights acquired in one state can be taken into account when claiming a pension in another country. For instance, such an agreement currently exists between Russia and Belarus. Contributory pensions can be received by individuals living outside of Russia, while social pensions are not exportable.

\subsubsection{Family Benefits}

The system of social protection of children and families comprises cash benefits and services for families with children., ${ }^{11},{ }^{12}$ Almost all childbirth-related cash benefits were subject to revision in 2007, as a part of the Government strategy to suspend population decline. Currently, the duration of paid maternity leave is 140 calendar days. The amount of the maternity allowance covered by social insurance is $100 \%$ of average earnings for the past two years preceding the leave, subject to an upper limit set annually by the Social Insurance Fund (SIF). For women whose contribution record is below six months, the amount cannot exceed the minimum wage

\footnotetext{
${ }^{10}$ The pension reform approved in 2018 implies a gradual transition to the retirement age from 55 to 60 years for women and from 60 to 65 years for men during the period 2019-2028.

${ }^{11}$ Federal Law No 81 of 19.05.1995 'On state allowances to citizens with children'; Labour Code of the Russian Federation (Articles 255-257); Federal Law No 255 of 29.12.2006 'On mandatory social insurance in case of temporary incapacity and maternity'; Federal Law No 256 of 26.12.2006 'On additional measures of support to families with children'; Decree of the President of the Russian Federation No 431 of 5.05 .1992 'On measures of social protection of families with many children'.

${ }^{12}$ Maternity and family allowances that are not covered in this section include lump-sum cash allowances in connection with childbirth granted to all nationals and a lump-sum cash transfer to mothers who gave birth to a second child (maternity capital).
} 
established in the region. All socially insured women are entitled to maternity allowance, irrespectively of their nationality.

Upon completion of maternity leave, mothers (fathers, adoptive parents, other relatives or guardians taking care of a child) are entitled to a paid parental leave that lasts up to 1.5 years. For socially insured individuals, the cash allowance for the period of parental leave (monthly child care allowance up to 1.5 years) equals $40 \%$ of the average monthly earnings for the past two calendar years, subject to lower and upper thresholds. Individuals whose contribution record is below six months are entitled to the minimum allowance. To receive this allowance, foreigners must be either permanent residents or socially insured. However, the above mentioned allowances are not conditioned by the country of birth, residence or nationality of the child.

The parental leave benefits are complemented by several means-tested monthly allowances. According to Russian law, eligibility for means-tested benefits is derived by comparing the individual, family or household income with the poverty line ${ }^{13}$. The monthly allowance for the third and subsequent children up to three years (introduced in 2017) is paid if family income is below the mean income in the region. The monthly allowances for the first and second children up to 1.5 years (introduced in 2018) are paid if family income is below $150 \%$ of the regional poverty line ${ }^{14}$. The benefit amounts are equal to $100 \%$ of the cost of regional poverty line ${ }^{15}$.

A monthly allowance for children up to 16 (18) years from poor families is the largest means-tested program in Russia in terms of its coverage, mainly due to weak targeting mechanisms (Popova 2013). The coverage though has been decreasing from over 40\% of the population under 16 years in 2010 to 27\% in 2015 (Rosstat 2018a). Since the decentralization reform carried out in 2005, the amounts, eligibility conditions, indexation and forms of payment of this benefit vary significantly from region to region.

Both permanent and temporary residents may be eligible to means-tested allowances, irrespectively of their insurance record, if they satisfy the conditions established in the region. The residency condition also applies to children, while the country of birth and nationality are irrelevant in these case. Nationals residing abroad are not entitled to claim any of these allowances as they are linked to employment or the residency status.

\footnotetext{
${ }^{13}$ The poverty line is referred to as the Minimum Subsistence Level (MSL) and equals the cost of a minimum basket of goods and services.

${ }^{14}$ In 2020, the age threshold was raised to three years and family income threshold was raised to $200 \%$ of the regional poverty line.

${ }^{15}$ In 2020, a new means-tested monthly allowance for children aged 3-7 years was introduced. The amount is equal to $50 \%$ of the cost of the regional poverty line and the family income should not exceed $100 \%$ of the regional poverty line.
} 


\subsubsection{Guaranteed Minimum Resources}

There is no single guaranteed minimum income benefit in Russia. Instead, there are a number of allowances, most of which are categorical allowances inherited from the Soviet social protection system ${ }^{16}$. The means-tested programs are poorly developed and account for a significantly smaller share of spending on social assistance.

The state social assistance scheme ${ }^{17}$ was established to provide relief to households in need. The program design, coverage and financing are regulated by the regions. Generally, the rules mix the notion of targeting with categorical provision of assistance, defining certain groups (pensioners, families with $3+$ children, students, etc.) eligible for the benefits. In addition, targeted assistance is often confused with one-time emergency assistance (e.g. loss of the breadwinner, severe illness, natural disaster). Starting from 2010, state social assistance can be provided in the form of a conditional cash transfer. ${ }^{18}$ The inter-regional variation in program rules is the highest among all means-tested schemes. The number of those who actually received a regular cash benefit amounted to 1.846 million people in 2016, and the number of recipients of a lump-sum payment was 1.633 million people, which altogether is less than $2 \%$ of the population (Rosstat 2018b). All foreigners legally residing in Russia can apply for state social assistance under the same conditions as national residents. Non-resident citizens are not entitled to claim this benefit.

A social supplement to pension ${ }^{19}$ is a special type of means-tested social assistance for the elderly people. Introduced in 2010, this benefit is provided to all nonworking pensioners whose total income is below the cost of a pensioner's poverty line in a given region. In 2015, 6.672 million people or $13 \%$ of pensioners received the supplement (Rosstat 2018b). The benefit can be paid to all permanent residents, regardless of their nationality. Russian citizens who have left for permanent residence abroad are not eligible.

\footnotetext{
${ }^{16}$ These are free services or discounts on payment for services, provided to vulnerable categories of the population (disabled people, war veterans, victims of the Chernobyl accident, etc.); but they also cover privileges for groups based on specific merits (mainly military) and their occupational status.

${ }^{17}$ Federal Law No 178 of 17.07 .1999 "On state social assistance".

${ }^{18}$ Beneficiaries have to sign a social contract to confirm their obligations (active job search, enrollment in a professional training, self-employment, school attendance, etc.) upon receipt of the benefit.

${ }^{19}$ Federal Law No 178 of 17.07.1999 "On state social assistance", article 12.1
} 


\subsubsection{Obstacles and Bilateral/Multilateral Social Security Agreements}

Foreigners' access to social benefits in Russia is determined by their legal status. Permanent residents and refugees have the same access to social benefits as Russian citizens, with few exceptions ${ }^{20}$. Temporary foreign residents are eligible for social insurance benefits (e.g. temporary incapacity and maternity-related cash allowances, public healthcare services) that are conditional on their employment status and social contribution record. They may be eligible for social assistance and family benefits that are available in their region of residence. On the other hand, Russian citizens permanently living abroad are not eligible for any other type of social benefits granted by Russia, apart from contributory pensions.

As far as obstacles are concerned, the Federal Migration Service has the right to recall a previously issued temporary or permanent residence permit if a foreigner cannot provide for himself/herself and his/her family at a level which is above the cost of the regional poverty line. Therefore, foreigners may be limited in terms of their rights of access to unemployment benefits and social assistance. Temporary staying workers may lose their job and, therefore, the right to stay in the Russian Federation, if they do not have a valid certificate of compulsory or voluntary health insurance.

A special group of foreigners who have preferential treatment in terms of accessing social benefits in Russia are nationals of Belarus. Being members of the Union State ${ }^{21}$ since 1996, the Russian Federation and Belarus have signed an agreement on cooperation in the field of social security and social assistance ${ }^{22}$. Citizens of Belarus permanently residing in Russia are equal to Russians in terms of their rights to social benefits and vice versa. This covers maternity benefits, unemployment benefits, old age, disability and survivor's benefits, benefits in the event of occupational disease or accident, and family benefits. Access to public healthcare is conditional on permanent residency status or on employment. When calculating social security benefits, the work experience acquired on the territory of both countries is taken into account. The benefits are paid by the country of residence. For child-related benefits (e.g. birth grant, child allowance up to 16(18) years), the child's place of residence is taken into account.

Citizens from the EAEU countries have similar advantages in access to social security in Russia. According to the agreement that came into force in 2015, migrants from these countries have the same rights for social security (except pensions) as citizens of the state of employment. This includes compulsory insurance

\footnotetext{
${ }^{20}$ For instance, foreign nationals are not eligible for the unemployment benefit, the maternity capital (a lump-sum benefit for women who have given birth to the second child) and various categorical cash benefits mainly targeted at the elderly and disabled individuals.

${ }^{21}$ See: http://eng.soyuz.by/. Last accessed 05 May 2020.

${ }^{22}$ Agreement between the Republic of Belarus and the Russian Federation on cooperation in the field of social security. Done at Saint Petersburg on 24 January 2006.
} 
against temporary incapacity and maternity insurance, compulsory insurance against occupational accidents and diseases and compulsory health insurance.

\subsection{Conclusions}

The eligibility of Russian nationals to social benefits depends either on their employment status and contribution record (for pensions and other social insurance benefits), or their residence status (for social assistance and healthcare). The place of residence is particularly important because the responsibility for legislative regulation and financing of most non-contributory social benefits and services lies with the regions. Since the priorities and budget capacities of regional authorities differ greatly across the regions, the overall level of social protection of citizens residing in different parts of the country may also differ substantially.

When deciding to permanently move abroad, Russian citizens lose their entitlement to claim most social benefits available in Russia, apart from acquired contributory old-age and disability pensions. On the other hand, the right of foreign residents to social benefits is essentially the same as that of their national counterparts, as long as they are legally employed and make social security contributions. However, there are two major exceptions: pensions and unemployment benefits. Pensions require a much longer contribution history and/or residence in Russia for at least 15 years. Moreover, foreigners are excluded from accessing unemployment benefits, although they can benefit from job search programs. Social assistance benefits provided at the regional level are typically available to all legal residents, foreigners included, with few exceptions. However, foreigners' access to social assistance benefits might also be constrained by the fact that their residency permit or temporary registration may be recalled if it becomes evident that they are not able to provide themselves and their family with the minimum resources (i.e. income above the regional poverty line).

Having said that, the most acute migration problem in Russia is the scale of illegal migration from CIS countries. Estimates of the number of illegal migrants vary from 3-4 million in autumn and winter to 5-7 million in spring and summer due to seasonal work (Iontsev and Ivakhnyuk 2012). Widespread illegal employment of foreign citizens is associated with considerable financial losses for Russia in the form of unpaid taxes and social contributions. At the same time, this group of migrants is completely deprived in terms of their employment and social rights.

Acknowledgements This chapter is part of the project "Migration and Transnational Social Protection in (Post)Crisis Europe (MiTSoPro)" that has received funding from the European Research Council (ERC) under the European Union's Horizon 2020 research and innovation programme (Grant agreement No. 680014). In addition to this chapter, readers can find a series of indicators comparing national social protection and diaspora policies across 40 countries on the following website: http://labos.ulg.ac.be/socialprotection/. This chapter uses results of a research project supported by the Basic Research Program at the National Research University - Higher School of Economics (HSE). 


\section{References}

Di Bartolomeo, A., Makaryan, S., \& Weinar, A. (Eds.). (2014). Regional migration report: Russia and Central Asia. Florence: European University Institute, Robert Schuman Centre for Advanced Studies, Migration Policy Centre.

Iontsev, V., \& Ivakhnyuk, I. (2012) Role of international labour migration in Russian economic development. CARIM-East Research Report 2012/04. European University Institute, Robert Schuman Centre for Advanced Studies.

Lopez-Calva, L. F., Lustig, N., Matytsin, M., \& Popova, D. (2017). Who benefits from fiscal redistribution in Russia? In G. Inchauste \& N. Lustig (Eds.), The distributional impact of fiscal policy: Evidence from developing countries. Washington, DC: World Bank.

Popova, D. (2013). Impact assessment of alternative reforms of child allowances using RUSMOD - The static tax-benefit microsimulation model for Russia. International Journal of Microsimulation, 6(1), 122-156.

Popova, D., Matytsin, M., \& Sinnot, E. (2018). Distributional impact of taxes and social transfers in Russia over the downturn. Journal of European Social Policy, 28(5), 535-548. https://doi. org/10.1177/0958928718767608.

Rosstat. (2017). The demographic yearbook of Russia. Moscow: Federal State Statistics Service (Rosstat).

Rosstat. (2018a). Russia in figures. Moscow: Federal State Statistics Service (Rosstat).

Rosstat. (2018b). Social situation and living standards of the population. Moscow: Federal State Statistics Service (Rosstat).

UN DESA. (2017). International migrant stock: The 2017 revision. Geneva: United Nations Department of Economic and Social Affaires. Available at: http://www.un.org/en/development/ desa/population/migration/data/estimates2/estimates17.asp.

Open Access This chapter is licensed under the terms of the Creative Commons Attribution 4.0 International License (http://creativecommons.org/licenses/by/4.0/), which permits use, sharing, adaptation, distribution and reproduction in any medium or format, as long as you give appropriate credit to the original author(s) and the source, provide a link to the Creative Commons license and indicate if changes were made.

The images or other third party material in this chapter are included in the chapter's Creative Commons license, unless indicated otherwise in a credit line to the material. If material is not included in the chapter's Creative Commons license and your intended use is not permitted by statutory regulation or exceeds the permitted use, you will need to obtain permission directly from the copyright holder.

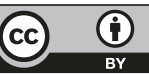

